\title{
Africans and African-Americans: Building Bridges that Break the Barriers of Mutual Ignorance and Self-Hatred
}

\author{
Abolade Ezekiel Olagoke, Ph.D. \\ Associate Professor of Sociology \\ Waynesburg University \\ $51 \mathrm{~W}$. College Street \\ Waynesburg, PA
}

\begin{abstract}
The purpose of this paper is to examine the statement that "more than an hyphen separates Africans and AfricanAmericans."The perpetuation of ignorance about Africa and Africans through history or lack of it, through the media and through centuries of stereotypes on both sides of the Atlantic has further exacerbated animosity, distrust and hateful disconnect. The paper interrogates the lived in experiences of Africans and Africans in the United Statesover the last three decades. In view of biological and cultural assimilation between the two groups through intermarriage and other forms of secondary group interactions, this paper addresses the historical, cultural, and religious Africanisms observed in both groups. The significance of the paper is to provide potential avenue for further dialog that will enhanceand illuminate the process of building bridges across the various forms of division.This paper is a product ofresearch using participant observation and family interactions in both communities over the last twenty years.
\end{abstract}

Keywords:_Africans, African Americans; dis-Africanization; mimetic theory; Africanisms; inter and intra ethnic racism; Christianity. Girard.

The roots we had in Africa continue to be important, necessary, life-affirming sources. But roots are ultimately for trees; and we must become new trees, striking out, reaching out, seeking new levels, new possibilities, here on this new shores. ${ }^{1}$ (Harding \& Ikeda, 2013)

\section{Introduction}

A cursory observation of Africans and African Americans in the United States is reminiscent of the story once shared by Maya Angelou when she met an elderly woman in Ghana. Struck by the presence and resemblance of Maya Angelou, the old woman asserted that she reminded her of her long departed ancestor. Similarities and variations in skin color and other physical features usually reminds Africans and African Americans of the long and horrible history of slavery that brought millions of Africans into the New World. In the first year of the author's sojourn in the United States, an middle aged African American who worked for a gas company replacing gas tanks for cooking called me and suddenly burst into tears. When I asked why he was weeping, he responded: "down the line, I am convinced we are related." In the African cultural parlance, the elders would say "he smelled the blood."

But sporadic stories like these do not erase the historical problems that the two groups often wrestle with sometimes subliminally. This core historical fact sometimes prompt people to wrestle with the problem of evil: why did slavery happen? Why was Africa colonized? Why do people suffer? Why do minorities often have their back pushed against the wall? Responses to these questions vary depending on the particular lived in experiences of Africans and African Americans. As in every other form of theodicy, there are no simply or satisfying answers. It is complicated. It is not Hollywood or Nollywood or Gallywood movie. ${ }^{2}$ We are also dealing with a cultural problem. African immigrants coming to the United States have a distinctively different cultural experiences from their American counterparts. Whether it is in the area of language, identify formation, education, religion and other forms of socialization that shape the individual from the "womb to the tomb" the differences can be glaring.

\footnotetext{
${ }^{1}$ Vincent Harding, The Other American Revolution, Center for Afro-American Studies, University of California Press, Los Angeles, 1980, page 202.

${ }^{2}$ Nollywood and Gallywood are the names of the movie production companies in Nigeria and Ghana respectively - named so to be in line with Hollywood in the United States.
} 
Even in Africa itself, distinctively agents of socialization exist from one ethnic group to another. In essence, in a continent of over one billion people, cultural homogeneity is not the norm. By and large, Africa is often seen or noted as a country rather than a continent that is big enough to fit the entire US three times with spaces left. The remarkable ignorance of both cultural and people's history of the continent is not limited to African Americans in view of the various kinds of questions about the continent often posed even by college educated individuals in the United States.

After Congress passed the Hart-Cellar Immigration Act of 1965, which allows people from the so called third world countries to emigrate to the United States, this has paved the ways for Africans to live here over the last few decades sometimes intermarrying with the native African Americans. In fact, we now have first, second, and third generation African immigrants some of who never knowing any other country but the United States. In view of biological and cultural assimilation between the two groups through intermarriage and other forms of secondary group interactions, it is imperative to tell their diverging and often converging stories. The significance of the paper is to provide potential avenue for further dialog that will enhance and illuminate the process of building bridges across the various forms of division. The paper is a product of research using participant observation and family interactions in both communities over the last twenty years.

\section{Methodology}

The author lived in Denver Colorado for over a decade both as a student and an employee of the United States Postal Service. Apart from being married to an African American woman who was a native of Chicago, the author has had the opportunity to live in their communities, worship in their churches and also engage in community related activities especially in Chicago. The locus of this research is in a congregation in Aurora Colorado where many ethnicities worshipped at the time and still do today even though the church is now in a different location from where the focus of this paper was done. The church, Hands On Christian Church prides itself as an interracial, inter-denominational and inter-ethnic place of worship with a quarter of the congregation being African Americans, about a dozen whites and Hispanics with a sizeable number of Africans. All in all, it averaged about one hundred and fifty regular members. The church also participates with other churches in the Denver Metro Area. The methodology employed was participant observation which was not limited to the church but also to other ceremonies: naming of newborns; house and car blessings; burials, and birthdays.

\section{Hands on Christian Church, Aurora, Colorado}

The missionary goals and objectives of Hands On Christian Church is to reach out to African Americans in the Denver, Colorado area. There are three reasons for this mission. First, the pastor himself is from an area in Nigeria that was once ravished by slavery. ${ }^{3}$ In this regard, he sees African Americans as brothers and sisters long separated by centuries of enslavement and detachment from motherland. Second, his work with young blacks in church and counseling sessions has given him a desire to be a role model to those in need. Third, some members of the church are African Americans, either single or intermarried to Africans, thus strengthening the bond of extended family and community of faith in Hands On Christian Church. A member of Hands On Christian church once observed that more than an "hyphen" separates Africans and African Americans. Through most of the Africans brought involuntarily to the New world were mainly from western or central Africa, the differences associated with geographical distance and culture that now span four centuries sometimes makes distant cousins look askance at each other. African Americans interviewed for this study were asked whether they had ever encountered an African and, if so, what their first reaction to this encounter had been. Responses included, "Well, I really do not know the difference until the African speaks and an accent is noted." Others say they are curious about why the African is sometimes aloof toward them or tends to gravitate toward white people. Others note that similarity of skin color fosters mutual identification in a culture where whites are predominant. As earlier indicated, a central ministry of the Hands On Christian church is to bridge the centuries old gulf among African descendants in the diaspora. In presenting the mission of the church in early 2001, the pastor emphasized his intent to reach out to African Americans. African Americans constitute an important part of the congregation of Hands on, and the pastor has invited a few to speak in Sunday services. Furthermore, his work with the inner city church, Church in the City, located on Colfax and York streets in Denver, is a vital element of his missiological goals to reach urban young blacks. As one of the pastoral staff of Church in the City, he has counseled members of rival gangs in the black community.

\footnotetext{
${ }^{3}$ The pastor comes from Oshogbo area of southwestern Nigeria. Interestingly enough, this was the area where during the slave trade, a young man by the name of Samuel Ajayi Crowther was captured and sold into slavery. He later became the first African Bishop after the abolition of slave trade. In fact, he was responsible for the translation of Yoruba Bible. Mudimbe(Bates, Mudimbe, \& O'Barr, 1993)made frequent references to Bishop Crowther's ministry in the Niger Delta area of Nigeria (See The Invention of Africa, Bloomington: Indiana University Press, 1988.
} 
During the past couple of years, two trips have been made to Africa involving African American members of the church. This represented an effort to bring reconciliation, and to acculturate the two groups by debunking the stereotypical images of Africa that have been perpetuated by the media.

\title{
What Is Africa To Africans And African Americans?
}

Marx in(Marx, Engels, \& Tucker, 1978)once asserted that "The tradition of all the dead generations weighs like a nightmare on the brain of the living." ${ }^{, 4}$ This statement is particularly applicable to the experiences and consciousness of Africa by Africans and African Americans. For African Americans, vestiges of Africanisms are perceived, but a primary effect of slavery has been a gradual process of dis-Africanization. This took the form of "divide and conquer" tactics where slaves with similar linguistic and ethnic origins were deliberately separated to discourage rebellion and revolts. As Ali Mazrui once observed, this process powerfully conveyed the message that, "Remember you are not Africans." A(Mazrui et al., 1986)spects of tribal lives, like drumming and dancing, were labeled pagan and primitive and systematically discouraged. In light of these various forms of disAfricanization, Countee Cullen(Cullen, 1947) asks:

\author{
What is Africa to me \\ Copper sun or scarlet sea \\ Jungle star or jungle track \\ Strong bronzed men, or regal black \\ Women from whose loins I sprang \\ When the birds of Eden sang? \\ One three centuries removed \\ From the scenes his fathers loved \\ Spicy grove, cinnamon tree \\ What is Africa to me? ${ }^{5}$
}

The question, "What is Africa to me?," remains a perennial one in the light of the experiences of both Africans and African Americans. It is not that the memories of Africa were immediately jettisoned, but negative caricature of the continent remains problematic in the present day. As Magubane (Magubane)observes,

An examination of Western European and American literature, motion pictures, cartoons and even casual conversations reveals the fact that in the Western world, Africa and its people are still viewed as a land of primitive childhood, if not a country of wild animals and wild people. ${ }^{6}$

African Americans' consciousness of Africa should be interpreted in light of the experience of slavery and racism, past and present. The ambiguity of relating to the continent is further exacerbated by the "pseudo philosophical, sociological and psychological ideas that assigned a subaltern place to Africa and its people in the general world history." This ambiguity affects the ways blacks identify with Africa. It is sometimes a combination of pride and prejudice, rejection and attraction, cultural affirmation and cultural distancing. The converse side of Countee'squestion is an African immigrant's rendition of it. AkinsolaAkiwowo was a Nigerian student at Morehouse College, and expressed considerable frustration on speaking about Africa in a foreign land:

Shall I sing your song, Africa in this strange land of hate and love?

Shall I sing to them whose forebears were torn away from you long ago?

For they know you not, but believe all the strange and gory stories

They oft have read and seen in film; apes, thick jungles and men with spears,

And nude women with pancake lips, they have not seen how, what you are;

That long estrangement shut their eyes, some see no beauty in our songs,

Some mock the gorgeous robes that we wear,

Some say you are still a thing of shame!

But some are kind, understanding, good, eager of hearts or purpose true,

\footnotetext{
${ }^{4}$ Robert C. Tucker, (ed.), The Marx-Engels Reader, (New York: W.W. Norton and Company, 1975), 595.

${ }^{5}$ Countee Cullen, On These I stand, Harper and Row, New York, 1927.

${ }^{6}$ Bernard Makhosezwe Magubane, The Ties That Bind: African-American Consciousness of Africa, Africa World Press, Inc., New Jersey, 1987, page VIII

${ }^{7}$ ibid, page VIII.
} 
But these are few, painfully few. ${ }^{8}$

The tension in relating to Africa is expressed by two contemporary African Americans, Cornel West and Keith Richburg. Cornel West is an African American professor of philosophy of religion at Princeton University and is also regarded as a social philosopher and critic. West was once married to an Ethiopian woman, and in one of his books, Keeping Faith, (1993), he reminisces about the tensions associated with being black in the United States and his occasional longing for "home."

After nine generations of family roots in America I feel an urge to

leave, to live in the house bequeathed to my wife and me by our mother. This urge rests on neither a romantic attachment to Africa nor a paternalistic commitment to uplift Ethiopians. Yet Africa does have a special appeal to me that Asia or Antarctica lack. And my project of prophetic criticism does commit me to promote the wise expansions of democratic practices in Ethiopia - as elsewhere. My thoughts of making Ethiopia my "home" are not based on brutal experiences of being black in America, or the relative paucity of enjoyable relations with Americans of all hues and colors. But in all honesty, the extent to which race still so fundamentally matters in nearly every sphere of American life is - in the long run depressing and debilitating. And my good fortune to have such fine friends across the racial divide is certainly not sufficient reason to be naively optimistic about America. ${ }^{9}$

It is not that West naively romantizes Africa or expects Ethiopia, where his wife comes from, to be completely devoid of the social and political problems endemic to many parts of the world. However, the significance of Ethiopia in African American consciousness cannot be overstated. First, besides providing the historical and biblical link to the ancient world, Ethiopia is one of the two African countries that did not suffer the fate colonialism. Secondly, Ethiopia successfully defeated the fascist government of Italy when it was invaded in 1935. As Daniel Thwaite (Thwaite, 1936)writes,

Ethiopia's prestige in Africa, consequent upon her triumphant success in repelling invasion and having remained unconquered throughout the centuries, is practically unfathomable. To the Africans in general, not only to those who invoked her as a liberator, she stands as a granite monument, a living exponent and testimony of the innate puissance of the black race, the shrine enclosing the last sacred spark of African political freedom, the impregnable rock of black resistance against white invasion, a living incarnation of Africa's independence. ${ }^{10}$

The Italian defeat at the hands of Ethiopians was a source of joy and succor to African Americans who saw this victory as a testament of hope for the future and liberation of the entire continent. Magubane emphasized the multifaceted roles of the NAACP ${ }^{11}$ and the Asia-African conference held in Bandung in further sensitizing the consciousness of blacks to the plight of Africans under colonial bondage on the continent.

It is in this light that when Ghana became independent of Britain in 1957 that the occasion was attended by scores of African Americans, including Dr. Martin Luther King Jr. and W.E. B. Du Bois. The jubilation on the part of the attendees was eloquently expressed by Du Bois experience(Du Bois, 1962):

I came to Africa

Here at last, I looked back on my dream

I heard the voice that loosed

The long-locked dungeons of my soul

I sensed that Africa had come

\footnotetext{
${ }^{8}$ (Wamba, 1999)Quoted in Philippe Wamba, Kinship: A family’s journey in Africa and America, Dutton Book: New York, 1999 , page 237.

${ }^{9}$ Cornel West, Keeping Faith, Philosophy and Race in America, New York: Routledge, 1993, page Xv.

${ }^{10}$ Daniel Thwaite, The Seething African Pot, Constable and Company, London, 1936, page 207

${ }^{11}$ The NAACP (National Association for the Advancement of Colored People) was not just an organization that catered to the interest of blacks in the United States alone, key members like Du Bois were outspoken critics of colonialism. (See Magubane, 1987, page 160.
} 
Not up from Hell, but from the sun of Heaven's glory. ${ }^{12}$

The struggle for liberation from colonization and its oppressive effects was highlighted by Dr. King during the civil rights movement. When asked what role should Africans play in the ongoing struggle for civil rights by blacks in the United States, Dr. King (King \& Washington, 1986)responds,

I think that in every possible instance Africans should use the influence of their governments to make it clear that the struggle of their brothers in the U.S. is part of a worldwide struggle. In short, injustice anywhere is a threat to justice everywhere, for we are tied together in a garment of mutuality. What happens in Johannesburg affects Birmingham, however indirectly. We are descendants of the Africans. Our heritage is Africa. We should never seek to break the ties, nor should the Africans. ${ }^{13}$

King's message, which transcends a particular ethnic or geographic location, is still instructive today, especially given the bitter diatribes that have occurred in recent years between some figures in the African and African American communities. A case in point is the recent book by Keith Richburg and Tunde Adeleke, that features powerful invectives bordering on outright racism. Tunde Adeleke is a Nigerian was a professor of history at the University of Montana. Adeleke describes the role of African middlemen in enslaving fellow Africans into the New World, and argues that black Americans have returned the favor by being implicated in African colonial project and the subsequent subversion of Africa's independence. He examines the works and lives of three black American nationalists, Alexander Crummell, Henry McNeal Turner, and Martin Delany and Adeleke (Adeleke, 1998)concludes his work with a poignant indictment:

The most critical and substantive character of late nineteenth century black American nationalism, therefore, was not so much its AngloSaxon or Anglo-American adaptations, reflected in its assertion of superiority over indigenous Africa, but the extent to which these adaptations implicated Black American nationalists in the subversion of Africa's independence. Their socialization and maturation occurred within a Western cultural milieu. It is, however, their extrapolation of the values derived from this socialization, and the utilization of such values as the basis of redefining their relationship with Africa that is problematic. The contradictions in black American understanding and interpretation of African societies and values compelled some black Americans to identify with the schemes that ultimately destroyed African sovereignty. ${ }^{14}$

It is not that Adeleke errs in revealing some of the motives of black nationalists However, completely overlooking their positive intentions in the face of seemingly insurmountable odds is an uncharitable reading of these nationalists. Furthermore, Adeleke is remarkably silent about current African leaders who have succeeded plundered and pillaged the continent.

Similar rhetoric espoused by Keith Richburg (a black American) seems to face a crisis of irrelevance in both communities as it does not address the profound Afro-pessimism whether on the continent or among young people in the United States. It is not that it is unimportant to know history, but sometimes little or nothing is learned from an uncharitable reading of history.

An unbalanced presentation of history can adversely affect the next generation. For example, in a recent column in the Rocky Mountain News where reparations to both Blacks and Africans have been the locus of discussion, Joseph Perkins, an African American writes,

Indeed the enslavement of black Americans' African forebears is in some respect analogous to the biblical story of Joseph, sold into bondage by his brothers (much as warring African tribes sold their

\footnotetext{
${ }^{12}$ W.E.B. Du Bois, Freedomways, Volume 2, No. 1, Winter 1962, page 71.

${ }^{13}$ Martin Luther King Jr., A Testament of Hope: The Essential Writings of Martin Luther King, Jr. Harper and row Publishers, San Francisco, 1986, page 364.

${ }^{14}$ Tunde Adeleke, UnAfricanAnmerican: Nineteenth Century Black Nationalists and the CivilizingMission, The University Press of Kentucky, Kentucky, pages 151-152.
} 
black brethren into slavery). The Bible says that Joseph won

his freedom over time and ultimately rose to power and fortune

in his adopted homeland. He surpassed the brothers who consigned him to slavery. ${ }^{15}$

Apart from a poverty of analysis of the complex issue of slavery, especially in its international dimension, Perkins's article epitomizes some of the troubling aspects of history. First, Perkins is not prepared to hold all whites responsible for slavery or force them into some forms of reparations. Second, he implies that all Africans are responsible for enslaving blacks. Third, the biblical analogy as used by Perkins ignores the reconciliation and forgiveness exhibited by the biblical Joseph as he finally met with his brothers. Like Adeleke, Perkins is equally silent on the eventual role of Joseph in relating to his brethren who sold him to slavery. The biblical point of Joseph being sold into slavery would have made no sense for futuregenerations without the powerful reconciliatory hand of love extended by a forgiving Joseph, who by then had reached a position of prominence in Egypt.

Overall, the article by Perkins points to some troubling aspects of understandably latent resentment by blacks toward Africans, a resentment that revolves around the perceived culpability of Africans for the peculiar institution of slavery. Over one hundred members of Hands On, interviewed and who have dealt with African Americans intuit an apparent resentment or coldness. Not every encounter is negative, but it appears that centuries of spatial and cultural distancing in conjunction with stereotypical images of Africa have affected both groups. The problem is more pronounced among those who have attended colleges and witnessed some forms of voluntary segregation where blacks and Africans form their own enclaves.

A classic example of the sometime tenuous relationship between Africans and African Americans is the family story of PhilippeWamba, whose father is Zairean and mother an African American. Wamba is a graduate of Harvard University and he portrays his own journey between the two cultures in the United States. Wamba wrestled with the remarkable ignorance on the part of both Africans and African Americans sometimes leading to situations of finger pointing, resentment and bittervirtuperation. He alludes to an occasion at Harvard where sensitivity on both parts really was a cause for consternation and shock.

$\mathrm{He}$ and another African were called into the office of an African American professor at Harvard and the ensuing discussion focused on the problem of the new generation of African Americans who did not sufficiently understand the significance of black scholars like Du. Bois. Since Du Bois chose to live, die and be buried in Africa, the professor queried the two Africans about his plan, after consultation with the Du Bois family, to have his body exhumed from Africa. Shocked and bewildered, Wamba(Wamba, 1999)and his comrade could not believe that a group of African Americans would even dare to debate the possibility of exhuming the body of a black man who self-consciously identified with Africa. It is imperative to add in passing that Du Bois was a person whose legacy and scholarship transcended any particular borders and could in fact be described as one of the fathers and founders of world-wide Pan Africanism. To relegate him to a narrow, provincial footnote in history sounded bizarre and bewildering:

Not only do Africans who make it to the United States

have to contend with an entire new culture and society

they also have to come to terms with the often bewildering

attitudes of their distant American cousins. ${ }^{16}$

Africans do not fare better either. During my interviews at Hands On Christian Church, some Africans who have had negative experiences with African Americans often sounded defensive, emphasizing the differences in both cultures at the expense of similarities. Not a few of those married to African Americans dwelt not on their own faults and human failings, but rather on the negative traits of their spouse. When I questioned further and reminded them of four African members in the Hands On Christian church who have been married to African Americans for over a decade and have tried to work things out, they said, "It is better to marry them as Christians than as unbelievers. Others said, "It is a matter of luck." They do not use the same yardstick to judge the marital failures of Africans married to Africans in the congregation. It is this mental grid that the pastor aspires to break in order to create a ground for understanding and amity.

\footnotetext{
${ }^{15}$ Joseph Perkins, "Reparations for Blacks is Hokum" in Rocky Mountain News, September 5, 2001. As a counterpoint, see also Ezekiel Olagoke's response to Joseph Perkins in the Rocky Mountain News, September, 25, 2001. Similar sentiments have been expressed through conversations with African Americans.

${ }^{16}$ Philippe Wamba, Kinship: A Family’s journey in Africa and America, Dutton Book, New York, 1998, page 230 


\section{Sermonic References To Africa as A Method of Reconciliation}

In several sermonic references, the pastor has made comparative analogies between African Americans and the Jewish people in terms of relating to their respective "motherlands." He alluded to the fact that the Jewish people living in the United States or other parts of the world are seldom asked which tribe they belong as they seek to identify with the state of Israel. ${ }^{17}$ In this regard, the pastor's message is reminiscent of Thomas Cahill (Cahill, 1999)when he would constantly remind his congregation that African Americans need not be particularly bothered by which of the ethnic groups on the continent they belong before demonstrating solidarity and with the plight of those less fortunate It is not just a Christian thing, it is a human thing to do. This is consistent with King's (King \& Washington, 1986)statement that, "Injustice anywhere is an affront to justice anywhere." 18 With regard to the African plight, the pastor argues that it does not matter whether forms of injustice is carried out by whites or by fellow Africans, haters and looters of national treasury must be named and condemned, drawing copiously from prophets of the Bible like Amos and Micah.

The pastor's interest in relating positively to African Americans is an essential part of his calling as a preacher. First, he is a lover of Christ, and the Christian experience in the formative years of his life echoes the biblical injunction of God reconciling men and women unto Himself. Second, if God is active in the work of reconciliation, then we should be active in reconciling each other through the love of God to a loving and peaceful co-existence. He often reminds Africans in the congregation that the onus rests on them to identify with visitors to the church, especially African Americans. How else, he asks rhetorically, could African Americans know of the continent except by the positive lifestyle and example of Africans whose presence in this land, in this day and age, is a divine appointment.

In a recent testimony, an African American who visited Africa was given the opportunity to tell the congregation about his experience in the country of Nigeria. At one point he commented on his visit to Badagry in West Africa, a place where slaves were shipped to the new world. Seeing the chains that were used to fetter our ancestors, he saw the continuation of those chains today in the two communities. According to him, these chains currently take the form of economic and political oppression in African countries, the rapid rate of incarceration of African American males in the prison system in the United States, and the pervasive pessimism and nihilism afflicting young people in both communities.

\section{Analysis of African/African American Condition By Girardian Mimetic Theory}

A saying in the oral tradition among the Yoruba people of Nigeria holds that it is practically irrelevant to ask an handicap whose legs are wobbled or a hunchback why the load the person carries does not rest straight on his/her head in the traditional manner. The cause of the problem is not that the handicap's head or neck is not straight, but that the legs which support the upper part of the body are the source of the problem. Through a traditional understanding of this proverbial saying, it is important to analyze the communal frictions between the two communities through mimetic theory developed by Rene Girard (Fletcher, 2001)

This theory deals with origin of culture and society through the three pillars of religion: prohibitions, ritual, and myth. ${ }^{19}$

\section{Rene Girard And The Theory Of Mimetic Desire}

Mimetic desire, according to Girard, rests on the notion that human beings passionately subject to intense desires, sometimes looking at other human beings imitatively desiring what they have. This form of desire often takes a triangular form - the desire of a subject desiring an object. Girard defines mimetic desire as a "desire according to Another" as opposed to a desire according to Oneself." 20 How this theory illuminates some aspects of Afro-pessimism will be amply illustrated. This theory and its application to the issue of slavery, tribalism, ethnocentrism, youth violence and endemic corruption will provide a clearer understanding of these problems and a way out of the maze.

\footnotetext{
${ }^{17}$ The extent at which both cultures have borrowed from the history of the Jewish people in terms of being people of the book, chosen-ness and a sense of destiny cannot be overstated. Thomas Cahill stated it more profoundly: "Without the Jewish sense of destiny, both corporate and individual, without the Jewish sense of history and the meaning given to suffering, no part of the story that Christians tell themselves would make any sense whatever" (See Thomas Cahill, The World Before and After Jesus: Desire of the Everlasting Hills, Anchor Books, New York, 2001, page 317.

${ }^{18}$ King and Washington, page 364.

${ }^{19}$ Paul Fletcher, Violence, Desire and the Gospels: The Theory of Rene Girard, Famington Papers, The Farmington Institute for Christian Studies, Oxford England, November, 2001.

${ }^{20} \mathrm{ibid}$, page 2 . Rene Girard starts his popular work to underscore the universality of mimetic desire with a quotation from Aristotle Poetics 4: "Man differs from the other animals in his greater aptitude for imitation. (See Rene Girard, Things Hidden Since the Foundation of the World (translated by Stephen Bann and Michael Metteer, Stanford University Press, Stanford, 1987).
} 
This analysis will underscore the Hands On Christian church's mission and experiment in healing and reconciliation among the various ethnic groups represented in the congregation. Furthermore, it is important to compare African and African American experiences with the Jewish experience. This is important for two reasons. First, both communities have suffered from the vestiges of slavery and being a pariah people. Second, both communities identify with the God of Israel and his entry into human history through the coming of Jesus of Nazareth. Finally, the biblical message of hope and peace has shaped both communities in the past as well as the present. In fact, the entire project of members of Hands On Christian church is premised on the central role of Christianity in making one a better person as one relates to God and to fellow human beings.

Drawing on specific examples from the interviews, it was observed that the Girardian approach to religion addresses the possibilities, problems, voices and visions of both groups. This approach is valid because for the two groups, religion has been interwoven and interconnected in their diasporic experiences as well as their survival and living through the absurdity of existence in the United States._One Girard's major works (René Girard \& Williams, 1996)on mimetic theory is Violence and the Sacred, which maintains that violence is at the heart of the sacred and is found in all humans(Ren@ $\odot$ Girard, 1977). According to Girard, "Neither primitive nor modern man has yet succeeded in identifying the microbe responsible for the dread disease of violence. ${ }^{, 1}$ Girardian mimetic theory examines human relations in terms of both individual and personal constitution as well as the social structure. Mimetic theory further looks at human desires starting first from possessive, acquisitive forms to conflictual and violent forms of mimesis. Girard asserts the significance of appropriative mimicry in explaining the development of human culture, especially religious institutions. Even in the explanation of forms of violence, Girard underscores the poverty of explanations with economic and political causes. Discussing the universal nature of religious prohibitions, Girard suggests that:

Religious prohibitions make a good deal of sense when interpreted

as efforts to prevent mimetic rivalry from spreading throughout

human communities. Prohibitions and taboos are often ineffectual and

misguided but they are not absurd, they are not rooted primarily in

irrational fears since they bear on violence, on mimetic behavior, and on

the potential objects of mimetic rivalry. ${ }^{22}$

\section{Issue of Slavery Revisited - Girardian Explanation}

Explanations for the causes of slavery have been partly economic and partly political. To what extent are the religious factors instrumental to scapegoating those captured and sold and how is this scapegoating played out today in various forms of inter-ethnic and intra-ethnic racism especially between Africans and African Americans? Since the two groups have been greatly influenced by Christianity, how should the concept of the 'victim' be read in light of Girardian mimetic theory? To what extent are the two groups complicit toward the on-going forms of violence locally and globally? Finally, how does Girardian mimetic theory help in building new relationship across racial and cultural boundaries?

\section{Inter Ethnic Racism}

In the past, scientific, philosophical and theological arguments have been adduced to justify the enslavement of particular groups of people. For Africans and African Americans, the justification for their enslavement has taken many twists and turns. For Africans and African Americans, the shared experience of humiliation and subordination has often engendered Pan-African commitment and solidarity. During the interview, numerous persons said it is not possible for minorities or people of color to be racist. This contention is buttressed by the fact that one cannot be racist unless one has sufficient economic and political power to subjugate the oppressed class. The same argument is often made in African settings where "tribalism" spreads its destructive tentacles. Some of those interviewed have even gone so far as equating racism with tribalism. In one sense, it is possible for one tribal group with economic advantage to take the reins of governance for the benefit of their particular group. Nevertheless, it is possible for one to be racist or tribalistic without the trappings of power and privilege. This does not negate the fact that one can be a beneficiary of a policy by virtue of one's association by tribe, ethnic group or color of the dominant group in the society. I would in this regard define racism or tribalism as the composite of myopic, entrenched and provincial ways of looking at others outside the orbit of one's particular ethnic group with condescension and a feeling of superiority. Most people in the southern part of Nigeria where the author grew up tend to look at the northern Hausa ethnic group as backward and indifferent to education and social progress. The reason commonly given is the Islamic upbringing of northerners and

\footnotetext{
${ }^{21}$ Rene Girard, Violence and the Sacred (translated by Patrick Gregory), The Athlone Press, London, 1988, page 33.

${ }^{22}$ Rene Girard, The Girard Reader, edited by James G. Williams, (New York, The Crossroad Publishing Company, 2000), page 10 . 
lack of contact with the West, which the southern part of the country has had for centuries. In a classroom lecture in Nigeria, I remember vividly the Chancellor of the institution addressing the class of his experience when he was an undergraduate student at the University of Ibadan, located in the then capital city of the Yoruba people of Nigeria. According to him, most Yorubas were shocked in 1948 to see an Hausa man enrolled at the University of Ibadan and they did not hide their feelings of shock. He frequently overheard them say "What is an Hausa man doing in the University?" This example underscores the stereotypical and myopic categorization of a particular group of people. Often the subtle ways are imbibed as a child when one develops a particular mental grid for dealing with other people. The same applies to racism. Appiah (Appiah, 1992)describes this mental grid as "cognitive incapacitation,"

Like extrinsic racism, intrinsic racism can also often

be seen as ideological, but, since scientific evidence

is not going to settle the issue, a failure to see that it is

wrong represents cognitive incapacity only according

to certain controversial views about the nature of morality. ${ }^{23}$

The ideology of racism is frequently reinforced in terms of a dominant group's overwhelming use of political and economic power over a minority group. The role of cultural, ideological, economic and political capital in espousing the whims and caprices of the dominant group in a given culture cannot be discounted. However, the dominant ideological underpinnings of racism are often perpetrated among various ethnic groups, e.g., Asians against blacks and vice versa, Latinos against blacks and vice versa, and Chinese against Japanese or Koreans and vice versa. ${ }^{24}$

It is imperative to examine the many forms of intra and inter-ethnic racism ${ }^{25}$ between Africans and African Americans especially in the United States. In most aspects of conflictual relationships between Africans and African Americans, the vestiges of slavery, centuries of stereotypical depiction of Africa as primitive, barbaric and savage have been imbibed by blacks and such memories are consciously or unconsciously exhibited when African Americans relate to Africans. The same holds true of Africans. Sometimes enjoying a modified form of treatment because of their alien status, arrogance attitudes are often displayed among some Africans who ironically boast of their enviable position of not being among the descendants of slaves. ${ }^{26}$ To discredit this thoughtlessness, which often created tension and friction between the two groups, some members of Hands On Christian church comment had slavery persisted for another decade, some Africans with whom blacks relate today would have been part of the holocaust of slavery.

Additionally, it was observed that blacks sometimes play out memory of being sold by Africans in certain quarters, making relationships with their distant cousins rather conflictual. As blacks exhibit the cultural, religious, and philosophical forms of racism when they relate to out-groups like Africans, it leads to the same tactics of 'divide and conquer' with certain aspects of 'labeling' put on specific groups of people. It may take the form of religious or philosophical labeling on the part of those more closely associated with Western norms and values. For example, it is not uncommon for educated, Christian Africans and African Americans to exhibit triumphal forms of Christianity whereby they are grateful for being Christianized and saved from perdition, unlike their less fortunate brethren who still live under the cover of darkness, paganism and divine judgement. ${ }^{27}$

\footnotetext{
${ }^{23}$ Kwame Anthony Appiah, In My Father's House: Africa in the Philosophy of Culture, New York: Oxford University Press, 1994, page 15

${ }^{24}$ The documentary, "The Color of Fear" (produced by Lee MunWah, 1994) articulately demonstrated the interethnic dimension of racism in the United sates.

${ }^{25} 1993$ conversation with Black Students, Northern Baptist Theological Seminary, Lombard, Illinois. Some would not classify the inter-ethnic rivalry or prejudice, as bothering on racism. They will define racism as one group with more economic or political power lording it over the minority group. However, the mechanism can still be the same especially when the out-group is dehumanized and denigrated by whatever means necessary: longevity of status with the West, not being born in a Western culture, material possession and education.

${ }^{26}$ Such mechanically thoughtless statements are common among Africans who have had very bad experience with blacks (ongoing interview). See also Francis T. McAndrew and Adebowale Akande: "African Perceptions of Americans of African and European Descent" inJournal of Social Psychology, 1995, 135(5), 649-655; Joseph Takougang, "Recent African immigrants to the United States" in The WesternJournal of Black Studies, 1995, volume 19:1, pages 86-92.
}

\footnotetext{
${ }^{27}$ Interview with pastors in black churches, the biblical story of Joseph being sold into slavery is often invoked. In essence, there is a divine providence for slavery, making blacks to become eventual bearers of Christianity, Commerce and Civilization to their benighted brethren in Africa. Earlier forms of religious Pan Africanism invoked the biblical 'Ethiopian shall once stretched its hands to God' (Psalm 68). See a critique of this concept by Tunde Adeleke, UnAfrican American: Nineteenth Century Black Nationalistsand the Civilizing Mission, The University of Kentucky Press (1997).
} 


\section{Jewish Experience (Marx's Antisemitism)-Comparative Analysis With Africans And African Americans}

A few historical examples from the Jewish experience will be helpful in examining the conflictual relationship between Africans and African Americans. While it is incontrovertible that blacks and Jews share the same experience of slavery, albeit in different contexts, examples also abound of the similarities of the 'Babylonian captivity especially of their intellectual elite. In this regard, Marx's essay 'On the Jewish Question' readily comes to mind. In the essay, Marx responded to a fellow Jew, Bruno Bauer's anti-Semitic argument castigating fellow Jews. Marx affirmed that Bruno's views were written 'with boldness, perception, wit and thoroughness in language that is as precise as it is vigorous and meaningful. ${ }^{28}$

Paul Johnson (Johnson)noted that the anti-Semitism of Marx and other educated Jewish elite can be explained by their lack of adequate Jewish education, the impact of Enlightenment thinkers like Voltaire, Hegel and Spinoza, and selfhatred. This form of self-hatred, he argued pushed Marx into bitter vituperation against other Jews. On the African side, the tendency to associate Western education with utmost wisdom is not uncommon among educated Africans, sometimes making them look contemptuously at less privileged citizens from the countryside. Marx, for example, once referred to the Polish Jew, Ferdinand Lassalle, as a Jewish Nigger. ${ }^{29}$ Perhaps the most damaging critique of Jewish people by another Jew is seen in Marx's contrast of money and the God of Israel:

money is the jealous god of Israel, besides which no other god

may exist. Money abases all the gods of mankind and changes them

into commodities. Money is the self-sufficient value of all things. It

has, therefore, deprived the whole world, both the human world and

nature, of their own proper value. Money is the alienated essence of

man's work and existence: this essence dominates him and he worships

it. The god of the Jews has been secularized and has become the god of

this world. ${ }^{30}$

Paul Johnson's evaluation of Marx's work provides a critical history of the Jewish experience. However, his critique is sometimes a very uncharitable reading of Marx especially in the light of his overall work and context. Given the past ten years, the bringing down of the Berlin wall and the resurgence of religion in what some members of Hands On have described as the revenge of God, Marx's critique of capitalism and society may be dismissed as inconsequential, but can definitely not be ignored.

With regard to Africans and African Americans, the black sociologist, E. Franklin Frazier (Frazier, 1962)describes the pathological condescension of the black bourgeoisie to things African:

The repressed hostilities of middle-class Negroes to whites are not

only directed toward minority groups but inward to themselves. They

talk condescendingly of Africans and African culture, often even

objecting to African sculpture in their homes. They are insulted if

they are identified with Africans. They refuse to join organizations

that are interested in Africa. If they are of mixed ancestry, they

may boast of the fact that they have Indian ancestry. ${ }^{31}$

Frazier is not alone in making these observations. Across the Atlantic, the crisis of the Nigerian intellectual class is apparent in the classification of Nigerian society. Obafemi Awolowo, a leading advocate of egalitarianism, (Awolowo, 1966)divides the Nigerian masses into four distinct groups: the educated class of professionals, teachers and clerks, the merely enlightened traders and artisans, the chiefs, and lastly the ignorant masses who will not be bothered by politics because their preoccupation is in search for food, clothing, and shelter of a wretched type. ${ }^{32}$

Anti-Semitism is not limited to Jews against Jews or the historical forms of anti-Semitism resulting in Jewish persecution and oppression. In recent years, despite the collaborative efforts of Jews with blacks during the civil rights in the United States, waves of black anti-Semitism have surfaced. This underscores inter-ethnic forms of racism not dissimilar to the ones perpetuated by the white dominant group. Cornel West (West, 1982)suggests that black antiSemitism is founded on three basic pillars, one of which is described below:

\footnotetext{
${ }^{28}$ Paul Johnson, A History of the Jews, New York: Harper and Row Publishers, 1987, page 351.

${ }^{29}$ ibid, page 350 .

${ }^{30}$ Robert C. Tucker, The Marx-Engels Reader, (New York: W.W. Norton \& Company 1978) page 50

${ }^{31}$ E. Franklin Frazier, Black Bourgeoisie, The Rise of a New Middle Class in the United States, Macmillan Publishing Company, New York, page 186

${ }^{32}$ Obafemi Awolowo, Path to Nigerian Freedom, Oxford University Press, Ibadan, 1947, pages 31-32. 
Black anti-Semitism is a form of underdog resentment and envy, directed at another underdog who has "made it" in American society. The remarkable upward mobility of American Jews rooted chiefly in a history and culture that places a premium on higher education and self-organization - easily lends itself to myths of Jewish unity and homogeneity that have gained currency among other groups, especially among relatively unorganized groups like black Americans. ${ }^{33}$

Cornel West's observation is instructive here. African anti-Semitism has not been noticeable among recent immigrants from the continent principally because Africans at Hands On have not had contiguous dealings with Jews to have reason for such anti-Semitism. Instead, almost every member I interviewed and interacted with (over 100) uncritically allude to Israel's special place in God's scheme of things and believe that any nation that blesses her will be blessed and vice versa.

The question arising from the foregoing is to what extent colonization of the mind is detrimental to communal wellbeing and grassroot solidarity, whether the colonization is internal in the African American sense or external in the African sense? Advocates for the "decolonization of the African mind" often argue that until this is done, the future is rather bleak for Africans. It is also argued that it is an uphill task for those trained and educated in Western Enlightenment tradition to not exhibit the same stereotypical traits espoused by Western thinkers like Kant, Hegel, David Hume and Joseph Conrad. These thinkers' denigration of Africa as having no history, no culture and no civilization has often been imbibed by both Africans and African Americans as they relate to each other. Cornel West, despite his adoration and deep intellectual respect for W.E.B. Du Bois argues that Du Bois was still a product of the enlightenment worldview.

In the religious sphere, the same is true in the elevation of Christian faith. Noted theologians like Samuel Ajayi Crowder, a Yoruba born Nigerian sold into slavery, and the black American nationalist, Alexander Crumwell, and others who, though blacks and Africans relate to Africa with the same condescension exhibited by European missionaries. $^{34}$ Part of Mudimbe's three-fold definition of the colonial project (Mudimbe, 1988)includes the reformation of the African mind which has been predetermined by the colonial powers as nothing but tabula rasa. ${ }^{35}$ Mudimbe himself once asserted that for the first few years of existence, "I thought, dreamt and spoke in French." ${ }^{36}$ The linguistic hegemony of various colonial languages in Africa is often seen by opponents, not as an asset but a liability. This accounts in part for the varying forms of double consciousness on the part of both Africans and African Americans.

\section{Excremental Assault And Banality In African/African American Experience}

"Shit" is a very common word used in the United States to describe an uncouth manner or a situation that is bad, ugly, or demeaning. In the literal sense, it denotes excrement, feces, defilement, and dirt. While describing the anatomy of life in the death camps, Terrence Des Pres refers to the dehumanizing effect of Nazi SS soldiers preventing camp prisoners from performing daily, natural and necessary routine of cleanliness, normal body functioning and elementary hygiene. ${ }^{37}$ Because the Nazis forbade even ordinary use of toilets and other forms of privacy, prisoners had to defecate on themselves, living in their own filth, feces, and urine. At one time, the prisoners were described mainly as 'putrefying corpses walking on two legs.'

This is a classic picture of defilement and evil. The symbolism of evil is not only associated with defilement, but also with its accompanying misfortune - suffering, disease and sickness. Paul Ricouer makes these connections clear,

\footnotetext{
${ }^{33}$ Cornel West, Race Matters, Beacon Press, Boston, 1993, page 77. To back up West's argument above that Jewish upward mobility has been due to its culture placing great premium on higher education, a segment was aired on November 20, 2001 on ESPN 46 titled "Beyond The Glory" where historically a great number of Jewish people were price-fighters. With increasing interest placed on higher education, the number of boxers of Jewish origin began to dwindle. Boxing, the program concluded is now a predominantly black/Latino sport.

${ }^{34}$ See V .Y. Mudimbe, The Invention of Africa,Gnosis, Philosophy and the Order of Knowledge, Bloomington, Indiana University Press, 1988. See also Kwame Anthony Appiah, In My Father's House, Bloomington, Indiana University Press, 1994.

35 ibid, page 9.

${ }^{36}$ Mudimbe, 1997, page 49.

${ }^{37}$ From the moving "The Unbearable Lightness of Being." See also class lecture in summer program in theology, Oxford University, 2000.
} 
The anticipation of punishment, at the heart of the fear of the impure, strengthens this bond between evil and misfortune: punishment falls on man in the guise of misfortune and transforms possible sufferings, all diseases, all death, all failure into a sign of defilement. ${ }^{38}$

The banality of evil and assault associated with blackness or Africanness is an on-going existential predicament. For example, blackness is often associated with tragedy, misfortune, and bad luck as in the expressions "black Friday, black day, and black sheep of the family." Referring to these descriptive attributes of blackness, Lewis Gordon writes,

In Western culture, blackness is traditionally symbolic of evil, ugliness, filth, wretchedness, decay, and death. On the other hand, the very color of the black person is a mark of degradation, with bestial physical force, inclinations to violence simian athletic prowess, and a primitive and rapacious sexuality. ${ }^{39}$

The existential blackness of an African or African American has only recently been associated with positive notation. Since the sixties, this has taken the form, 'black is beautiful', and "I am black and I am proud." These are reactions to the demonisation of blackness and the existential angst associated with living in a racist culture. Blackness has been labeled as a sign of the Hamitic curse with reference to the Biblical Ham. To the African under this scenario, blackness is not only problematic, the place of origin presents a negative criterion of classification - Africa the dark continent, the heart of darkness, the Tarzan mentality of Africa as inhabited mainly by animals and jungle. To those who relate to the continent, it is an ambiguous relationship, a love and hate syndrome, pride and prejudice relationship and a dialectical logic of difference.

A classic example of this kind of mentality is demonstrated in Keith Richburg recent book, Out of America (1998), where he pronounces himself a racist. A Black racist! Not impossible. Keith is a reporter for the Washington Post whose recent work encapsulates what E. Franklin Frazier, the black sociologist characterized as the pathology of black bourgeoisie confusion ${ }^{40}$ as they relate to Africa and Africans. In fact, had the same work been written by a white person, all hell would have broken out. As a reporter who sojourned in Africa for three years, Richburg's catalog of evil and defilement of the continent led him to conclude that he wants no part of it. He goes so far as to nearly glorify slavery:

If [my] original ancestor hadn't been forced to make that horrfic voyage, I would not have been standing there that day on the Rusumo Falls bridge, a journalist - a mere spectator - watching the bodies glide past me like river logs. No, I might instead be one of them - or have met some similarly anonymous fate in any one of the countless ongoing civil wars or tribal clashes on this brutal continent. And I thank God my ancestor made that voyage. $^{41}$

\section{Scapegoating In The African- African American Experience}

The consequences of scapegoating black people is world-wide. For African Americans, even though slavery is abolished, racism still thrives. Several respondents expressed the danger that can result in driving while black (DWB), simply because one can be stopped by the police for trivial issues. A larger percentage of African American I have had conversation with said they have been victims of scapegoating on a regular basis. This is not just restricted to driving alone in a nicer brand of vehicle. They mentioned being followed suspiciously by police because they live in "nice" places like Smoky Hills where they are traditionally not expected to live. They say there is an on-going dilemma of being black when the normative color is white. Most members of Hands On Christian church say they are subject to an extra search and extra look when going through airports as they travel back and forth to their homelands. Relating to African Americans, not a few Africans have been accused to taking their jobs. In a period of recession, scapegoating mechanism are often directed at foreigners. Commenting on the notion of scapegoating, Girard draws a contrast between the scapegoat as ritual and scapegoat as effect:

\footnotetext{
${ }^{38}$ Paul Ricoeur, The Symbolism of Evil (translated by Emerson Buchanan), Boston, Bacon Press, 1967, page 27.

${ }^{39}$ Lewis R. Gordon, (eds.), Existence in Black, An Anthology of Black Existential Philosophy, Routledge, New York, 1997, page 209.

${ }^{40}$ Frazier, 1967, page 186.

${ }^{41}$ Quoted in Philippe Wamba, Kingship, A Family's journey in Africa and America, Dutton Book, New York, page 26 
By a scapegoat effect I mean that strange process through whichtwo or more people are reconciled at the expense of a third party who appears guilty or responsible for whatever ails, disturbs, or

frightens the scape-goaters. They feel relieved of their tensions and they coalesce into a more harmonious group. They now have a single

purpose, which is to prevent the scapegoat from harming them, by expelling and destroying him. ${ }^{42}$

The aforementioned scapegoating mechanism is illustrated in religious and ethnic forms of violence in Africa when victims of war are enslaved. For example, the on-going enslavement of black Sudanese by their Arab rulers is predicated on a demonic interpretation of the Koran. In most cases, these victims belong to ethnic groups endowed with potentials envied by their captors or their lands have resources that are enviable. The choice of the victim for scapegoating, whether in enslavement, lynching or tribal wars is not necessarily random. Girard's acquisitive mimesis, where the material or human endowment of a person is lusted upon to acquire, often result in conflictual and violent crimes on the victims and is demonstrated by the plundering effects of these internecine struggles.

\section{Conclusion: Hands On Christian Church Response To The Banality Of Evil}

The pastor frequently alludes to the Jewish experience, whether in religious or in secular terms. He alludes frequently to history and God's dealing with the Jewish people, especially of the constancy of Israel living as strangers in foreign lands and the prophetic admonition to her not to forget Jerusalem (Psalm 127). For the Jewish people, the state and the land of Israel form a critical part of their thinking. It is not that the pastor tries to equate Israel, with Africa or vice versa, but parallels of history and experience in suffering and the overall problem of evil are frequently drawn.

A striking and inspiring tradition in the Jewish experience has been the ability not only collective celebration of memories of experience as seen in the biblical tradition but also to respond in a concrete way to the existential human condition. Examples abound. In the religious landscape, we have the prophetic and the messianic tradition in Israel. The secular equivalent is seen first, in the Marxist tradition, second, the Frankfurt school of critical theory, third the postmodern tradition. The aforementioned schools of thought were all led by Jewish intellectuals ( e.g. Adorno, Horkheimer, Lyotard) This is not to imply that only Jewish people have monopoly on learning. One also realizes that there are individuals, for example Dr. Martin Luther King Jr. and W. E. B. Du Bois in different historical epochs who have made indelible marks on their people and society in general. From this perspective, it is saddening to see the antiJewish climate (West, 1993)among some black leaders during the past few years. ${ }^{43}$

This is more so bearing in mind that shortly before Dr. King's death, Rabbi Abraham J. Heschel, said that "the whole future of America depends upon the impact and the influence of Dr. King." ${ }^{44}$ Such was the spirit of understanding and cooperation between the two communities during the civil rights era is sorely needed today between the two groups.

\section{Uncategorized References}

Adeleke, T. (1998). UnAfrican Americans : nineteenth-century Black nationalists and the civilizing mission. Lexington: University Press of Kentucky.

Appiah, A. (1992). In my father's house : Africa in the philosophy of culture. New York: Oxford University Press.

\footnotetext{
${ }^{42}$ Girard, page 12.

${ }^{43}$ Cornel West, Race Matters (1993)

${ }^{44}$ Quoted in Vincent Harding, Martin Luther King, The Inconvenient Hero, Orbis Books, New York, 1996, page ix.
} 
Awolowo, O. (1966). Path to Nigerian freedom (1st ed.). London,: Faber.

Bates, R. H., Mudimbe, V. Y., \& O'Barr, J. F. (1993). Africa and the disciplines : the contributions of research in Africa to the social sciences and humanities. Chicago: University of Chicago Press.

Cahill, T. (1999). Desire of the everlasting hills : the world before and after Jesus (1st ed.). New York: Nan A. Talese.

Cullen, C. (1947). On these I stand; an anthology of the best poems of Countee Cullen. New York; London: Harper \& brothers.

Du Bois, W. E. B. (1962). African Liberation. Freedomways, 2 (1), 71.

Fletcher, P. (2001). Violence, Desire and the Gospels: The Theory of Rene Girard. Paper presented at the Famington Papers, The Famington Institute for Christian Studies, Oxford England.

Frazier, E. F. (1962). Black bourgeoisie. New York,: Collier Books.

Girard, R. (1977). Violence and the sacred. Baltimore: Johns Hopkins University Press.

Girard, R., \& Williams, J. G. (1996). The Girard reader. New York: Crossroad.

Harding, V., \& Ikeda, D. (2013). America will be! : conversations on hope, freedom, and democracy. Cambridge, Massachusetts: Dialogue Path Press.

Johnson, P. A history of the Jews (First U.S. edition. ed.).

King, M. L., \& Washington, J. M. (1986). A testament of hope : the essential writings of Martin Luther King, Jr (1st ed.). San Francisco: Harper \& Row.

Magubane, B. The ties that bind: African-American consciousness of Africa.

Marx, K., Engels, F., \& Tucker, R. C. (1978). The Marx-Engels reader (Second edition. ed.). New York: Norton.

Mazrui, A. A. A., Bate, P., Copestake, T., WETA-TV (Television station : Washington D.C.), British Broadcasting Corporation. Television Service., \& Annenberg/CPB Project. (1986). The Africans [videorecording]. S. Burlington, VT: Annenberg/CPB Project,.

Mudimbe, V. Y. (1988). The invention of Africa : gnosis, philosophy, and the order of knowledge. Bloomington: Indiana University Press.

Thwaite, D. (1936). The seething African pot, a study of black nationalism, 1882-1935. London,: Constable.

Wamba, P. E. (1999). Kinship : a family's journey in Africa and America. New York: Dutton.

West, C. (1982). Prophesy deliverance! : an Afro-American revolutionary Christianity (1st ed.). Philadelphia: Westminster Press.

West, C. (1993). Race matters. Boston: Beacon Press. 